\title{
Thermodynamics of lon-exchange reaction in predicting the ionic selectivity of Auchlite ARA-9366 and Auchlite A-378 anion exchange resins
}

\author{
P. U. Singare*, A. N. Patange \\ Department of Chemistry, Bhavan's College, Munshi Nagar, Andheri (West), Mumbai, \\ Maharashtra 400058, India \\ *Tel No. + 9122 26256451/ 52, Fax No. + 912226256453 \\ *E-mail address: pravinsingare@gmail.com
}

\begin{abstract}
The paper deals with predicting the iodide ion selectivity of nuclear and non-nuclear grade anion exchange resins. The ionic selectivity prediction was made on the basis of thermodynamic data of $\mathrm{Cl}^{-} / \mathrm{I}^{-}$ion exchange reaction. It was observed that with rise in temperature from $30.0{ }^{\circ} \mathrm{C}$ to $45.0{ }^{\circ} \mathrm{C}$, the equilibrium constant $(K)$ values were observed to decreases from $59.77 \times 10^{-2}$ to $23.77 \times 10^{-2}$ for Auchlite ARA-9366 resins and from $9.01 \times 10^{-2}$ to $4.05 \times 10^{-2}$ for Auchlite A-378 resins. The decrease in $K$ values with rise in temperature, indicate exothermic ion exchange reactions having enthalpy values of -47.87 and $-39.51 \mathrm{~kJ} / \mathrm{mol}$ respectively. The high $K$ and low enthalpy values obtained for Auchlite ARA-9366 resins indicate their greater selectivity for the iodide ions in the solution as compared to Auchlite A-378 resins, when both the resins are present in chloride form.
\end{abstract}

Keywords: ionic selectivity; uni-univalent exchange; thermodynamic equilibrium constant; enthalpy; nuclear grade ion exchange resin; Auchlite ARA-9366; Auchlite A-378

\section{INTRODUCTION}

Ion exchange technique has attained considerable importance as a tool in both fundamental and industrial chemistry. The technique involves reversible interchange of ions between a liquid phase and solid material. Solid ion exchangers have cross linked polymer of high molecular weight as the base and an exchangeable cation or anion. In the cation exchange resin, for example exchangeable ion is $\mathrm{H}^{+}$of sulphonic acid group. In the anionic exchanger, exchangeable ion can be $\mathrm{Cl}^{-}$or $\mathrm{OH}^{-}$group. Most popular resins are produced by polymerizing styrene in the presence of divinyl benzene. Ion-exchange resins are produced and commercialized in a wide range of formulations with different characteristics, and have now a large practical applicability in various industrial processes, such as chemical, nuclear, pharmaceutical, food industry, etc. [1]. In present times organic ion exchange resins are not only used in nuclear industries for removal of radionuclide but also in general chemical industries for cleaning and decontamination processes [2-6]. Efforts to develop new ion exchangers for specific applications are continuing and various aspects of ion exchange technologies have been continuously studied to improve the efficiency and economy of their 
application in various technological applications [7-14]. By taking advantage of the fact that, under certain conditions, ion exchange media has a greater affinity for certain ionic species than for others, a separation of these species can be made $[15,16]$. However presence of chemically similar ionic species in the liquid waste will create difficulty in selection of suitable ion exchange media. Therefore, in the present investigation, based on the thermodynamic equilibrium constants attempts was made to understand the difference in iodide ion selectivity of the two closely related anion exchange resins Auchlite ARA-9366 and Auchlite A-378 in chloride form. It is expected that the present technique can be applied further to understand the selectivity behaviour of series of anion exchange resins towards different uni and multivalent ions in the solution. The experimental data generated from such studies will be useful in selection of suitable resin for various technical applications.

\section{EXPERIMENTAL}

The ion exchange resin Auchlite ARA-9366 and Auchlite A-378 as supplied by the manufacturer (Auchtel Products Ltd., Mumbai, India) were the anion exchangers in hydroxide form. The details regarding various physico-chemical properties of the two ion exchange resins are presented in Table 1.

Table 1. Physico-chemical properties of anion exchange resins.

\begin{tabular}{|c|c|c|c|c|c|c|}
\hline $\begin{array}{c}\text { Ion } \\
\text { exchange } \\
\text { resin }\end{array}$ & Matrix & $\begin{array}{c}\text { Functional } \\
\text { Group }\end{array}$ & $\begin{array}{c}\text { Mean } \\
\text { particle } \\
\text { Size } \\
\mathbf{( m m}\end{array}$ & $\begin{array}{c}\text { Moisture } \\
\text { content } \\
\mathbf{( \% )}\end{array}$ & $\begin{array}{c}\text { Operating } \\
\mathbf{p H}\end{array}$ & $\begin{array}{c}\text { Maximum } \\
\text { operating } \\
\text { temperature } \\
\left({ }^{\circ} \mathbf{C}\right)\end{array}$ \\
\hline $\begin{array}{c}\text { Auchlite } \\
\text { ARA-9366 }\end{array}$ & polystyrene & $\begin{array}{c}\text { quaternary } \\
\text { ammonium }\end{array}$ & $0.3-1.0$ & 50 & $0-14$ & 60.0 \\
\hline $\begin{array}{c}\text { Auchlite A- } \\
378\end{array}$ & polystyrene & $\begin{array}{c}\text { tertiary } \\
\text { ammonium }\end{array}$ & $0.3-1.2$ & 48 & $0-7$ & 60.0 \\
\hline
\end{tabular}

For present investigation, the resin grains of 30-40 mesh size were used. The soluble impurities of the resin were removed by repeated Soxhlet extraction using water and occasionally with distilled methanol to remove non-polymerized organic impurities. In order to bring about complete conversion of resins in chloride form, the resins were conditioned with $10 \%$ potassium chloride solution in a conditioning column. The resins were washed with distilled deionised water until the washings were free from chloride ions. The resins in chloride form were air dried over $\mathrm{P}_{2} \mathrm{O}_{5}$ and used for further studies. The exchange capacity of ion exchange resins was experimentally determined by the standard method [17] using sodium nitrate and titrating against standard silver nitrate solution. Ion exchange resins $(0.500$ $\mathrm{g}$ ) in chloride form were equilibrated with iodide ion solution of different concentrations at a constant temperature of $30.0^{\circ} \mathrm{C}$ for $3 \mathrm{~h}$. From the results of kinetics study reported earlier [18-36]; it was observed that this duration was adequate to attain the ion exchange equilibrium. After $3 \mathrm{~h}$, the iodide ion solutions in equilibrium with ion exchange resins in chloride form were analyzed for their chloride and iodide ion concentrations by 
potentiometric titration with standard $0.1 \mathrm{M}$ silver nitrate solution. From the results the equilibrium constant $K$ for the reaction

$$
\mathrm{R}-\mathrm{Cl}+\mathrm{I}_{(\mathrm{aq})}^{-} \leftrightarrow \mathrm{R}-\mathrm{I}+\mathrm{Cl}_{(\mathrm{aq})}^{-}
$$

was determined at $30.0^{\circ} \mathrm{C}$. The equilibrium constants $K$ for the above $\mathrm{Cl}^{-} / \mathrm{I}^{-}$system was determined for different temperatures in the range of $30.0^{\circ} \mathrm{C}$ to $45.0^{\circ} \mathrm{C}$.

In the present study, a semi-micro burette having an accuracy of $0.02 \mathrm{~mL}$ was used in the titrations against silver nitrate solution. The titration readings were accurate to $\pm 0.02 \mathrm{~mL}$. Considering the magnitude of the titre values, the average equilibrium constants reported in the experiment are accurate to $\pm 3 \%$.

\section{RESULTS AND DISCUSSION}

The equilibrium constants for reaction (1) can be written as

$$
K=\frac{\mathrm{c}_{\mathrm{R}-\mathrm{I}} \cdot \mathrm{c}_{\mathrm{Cl}^{-}}}{\left(A-\mathrm{c}_{\mathrm{R}-\mathrm{I}}\right) \cdot \mathrm{c}_{\mathrm{I}^{-}}}
$$

where, $A$ is the ion exchange capacity of the resin. For different concentrations of $\mathrm{I}^{-}$ions in solution at a given temperature, $K$ values were calculated and an average $K$ value for this set of experiments was found (Tables 2,3). Similar $K$ values were calculated for the $\mathrm{Cl}^{-} / \mathrm{I}^{-}$ system at different temperatures (Table 4 ). The $\log K$ values were plotted against $1 / \mathrm{T}$ (in Kelvin), which gives a straight line graph (Figure 1) from the slope of this graph enthalpy of the ion exchange reaction 1 was calculated (Table 4).

Table 2. Equilibrium constant for the ion exchange reaction (1) using Auchlite ARA-9366 resin. Amount of the ion exchange resin in chloride form $=0.500 \mathrm{~g}$, Ion exchange capacity $=2.3 \mathrm{meq} . / 0.5 \mathrm{~g}$,

\begin{tabular}{|c|c|c|c|c|c|c|}
\hline $\begin{array}{l}n \\
\omega \\
\omega \\
\tilde{E} \\
\tilde{E}\end{array}$ & 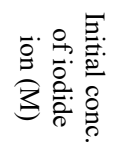 & 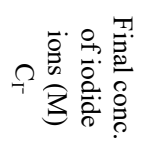 & 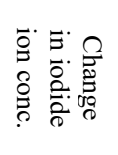 & 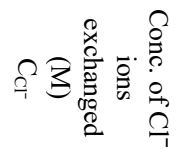 & 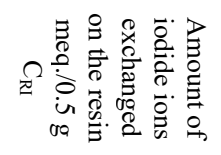 & 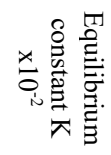 \\
\hline 1 & 0.010 & 0.001 & 0.009 & 0.009 & 0.45 & 218.92 \\
\hline 2 & 0.023 & 0.011 & 0.012 & 0.012 & 0.60 & 38.50 \\
\hline 3 & 0.054 & 0.036 & 0.018 & 0.018 & 0.90 & 32.14 \\
\hline 4 & 0.069 & 0.058 & 0.011 & 0.011 & 0.55 & 5.96 \\
\hline 5 & 0.094 & 0.084 & 0.010 & 0.010 & 0.50 & 3.31 \\
\hline \multicolumn{6}{|c|}{ Av } & 59.77 \\
\hline
\end{tabular}
Temperature $=30.0^{\circ} \mathrm{C}$. 
Table 3. Equilibrium constant for the ion exchange reaction (1) using Auchlite A-378 resin. Amount of the ion exchange resin in chloride form $=0.500 \mathrm{~g}$, Ion exchange capacity $=0.74 \mathrm{meq} . / 0.5 \mathrm{~g}$, Temperature $=30.0^{\circ} \mathrm{C}$.

\begin{tabular}{|c|c|c|c|c|c|c|}
\hline System & $\begin{array}{c}\text { Initial conc. } \\
\text { of iodide } \\
\text { ion (M) }\end{array}$ & $\begin{array}{c}\text { Final conc. } \\
\text { of iodide } \\
\text { ions (M) } \\
\mathrm{C}_{\mathrm{I}^{-}}\end{array}$ & $\begin{array}{c}\text { Change } \\
\text { in iodide } \\
\text { ion conc. }\end{array}$ & $\begin{array}{c}\text { Conc. of } \\
\mathrm{Cl}^{-} \text {ions } \\
\text { exchanged } \\
(\mathrm{M}) \mathrm{C}_{\mathrm{Cl}^{-}}\end{array}$ & $\begin{array}{c}\text { Amount of } \\
\text { iodide ions } \\
\text { exchanged } \\
\text { on the resin } \\
\text { meq./0.5 g } \\
\mathrm{C}_{\mathrm{RI}}\end{array}$ & $\begin{array}{c}\text { Equilibrium } \\
\text { constant } K \\
\mathrm{x}^{-2}\end{array}$ \\
\hline 1 & 0.0112 & 0.0064 & 0.0048 & 0.0048 & 0.24 & 36.00 \\
\hline 2 & 0.0244 & 0.0208 & 0.0036 & 0.0036 & 0.18 & 5.56 \\
\hline 3 & 0.0478 & 0.0448 & 0.003 & 0.003 & 0.15 & 1.70 \\
\hline 4 & 0.0732 & 0.0708 & 0.0024 & 0.0024 & 0.12 & 0.07 \\
\hline 5 & 0.0616 & 0.058 & 0.0036 & 0.0036 & 0.16 & 1.71 \\
\hline & \multicolumn{7}{|c|}{ Average K } \\
\cline { 2 - 7 }
\end{tabular}

Bonner and Pruett [37] studied the temperature effect on uni-univalent exchanges involving some divalent ions. In all divalent exchanges, the equilibrium constant decreases with rise in temperature resulting in exothermic reactions. Similar results were obtained in the present investigation for Auchlite ARA-9366 and Auchlite A-378 resins, during $\mathrm{Cl}^{-} / \mathrm{I}^{-}$uniunivalent ion exchange reactions having the enthalpy values of -47.87 and $-39.51 \mathrm{~kJ} / \mathrm{mol}$ respectively (Table 4). These results obtained here are very much identical to the results of our previous research work performed on the same system using Duolite 101-D and Tulsion A-33 anion exchange resins in which the variation of $K$ values with rise in temperature follow the same pattern indicating exothermic ion exchange reactions (Table 5) [38-41].

Table 4. Thermodynamics of ion exchange reaction $\mathrm{R}-\mathrm{Cl}+\mathrm{I}^{-}{ }_{\text {(aq.) }} \leftrightarrow \mathrm{R}-\mathrm{I}+\mathrm{Cl}^{-}{ }_{\text {(aq.) }}$

\begin{tabular}{|c|c|c|c|c|c|c|c|c|}
\hline Resins & \multicolumn{4}{|c|}{ Auchlite ARA-9366 } & \multicolumn{4}{c|}{ Auchlite A-378 } \\
\hline Temperature $\left({ }^{\circ} \mathrm{C}\right)$ & 30.0 & 35.0 & 40.0 & 45.0 & 30.0 & 35.0 & 40.0 & 45.0 \\
\hline $\begin{array}{c}\text { Equilibrium Constant } \\
(\boldsymbol{K}) \times 10^{-2}\end{array}$ & 59.77 & 33.56 & 27.20 & 23.77 & 9.01 & 5.00 & 4.73 & 4.05 \\
\hline Enthalpy $(\mathrm{kJ} / \mathrm{mol})$ & \multicolumn{4}{|c|}{-47.87} & \multicolumn{4}{c|}{-39.51} \\
\hline
\end{tabular}

Table 5. Comparison of thermodynamic equilibrium data of ion exchange reaction $\mathrm{R}-\mathrm{Cl}+\mathrm{I}^{-}{ }_{\text {(aq.) }} \leftrightarrow \mathrm{R}-\mathrm{I}+\mathrm{Cl}^{-}$(aq.) using different resins.

\begin{tabular}{|c|c|c|c|c|}
\hline Ion Exchange Resins & $\begin{array}{c}\text { Temperature } \\
\text { Range }\left({ }^{\circ} \mathrm{C}\right)\end{array}$ & $\begin{array}{c}\text { Equilibrium } \\
\text { Constant K range }\end{array}$ & $\begin{array}{c}\text { Enthalpy } \\
(\mathrm{kJ} / \mathrm{mol})\end{array}$ & References \\
\hline Tulsion A-33 & $30-45$ & $37.68-20.93$ & -8.43 & {$[38,39]$} \\
\hline Duolite 101-D & $30-45$ & $29.28-16.01$ & -12.77 & {$[40,41]$} \\
\hline Auchlite ARA-9366 & $30-45$ & $59.77-23.77$ & -47.87 & This Study \\
\hline Auchlite A-378 & $30-45$ & $9.01-4.05$ & -39.51 & This Study \\
\hline
\end{tabular}


The equilibrium constants $K$ for uni-univalent ion exchange reaction (1) increases in the order Auchlite A-378 < Auchlite ARA-9366. Therefore, the selectivity of these ion exchange resins in chloride form towards $\mathrm{I}^{-}$ions increases in the same order. Similarly, the enthalpy values for the reaction (1) increases in the order Auchlite ARA-9366 < Auchlite A-378. The high $K$ and low enthalpy values obtained for Auchlite ARA-9366 indicates their superior performance in terms of selectivity towards iodide ions in solution as compared to Auchlite A-378, when both of the resins are present in chloride form.

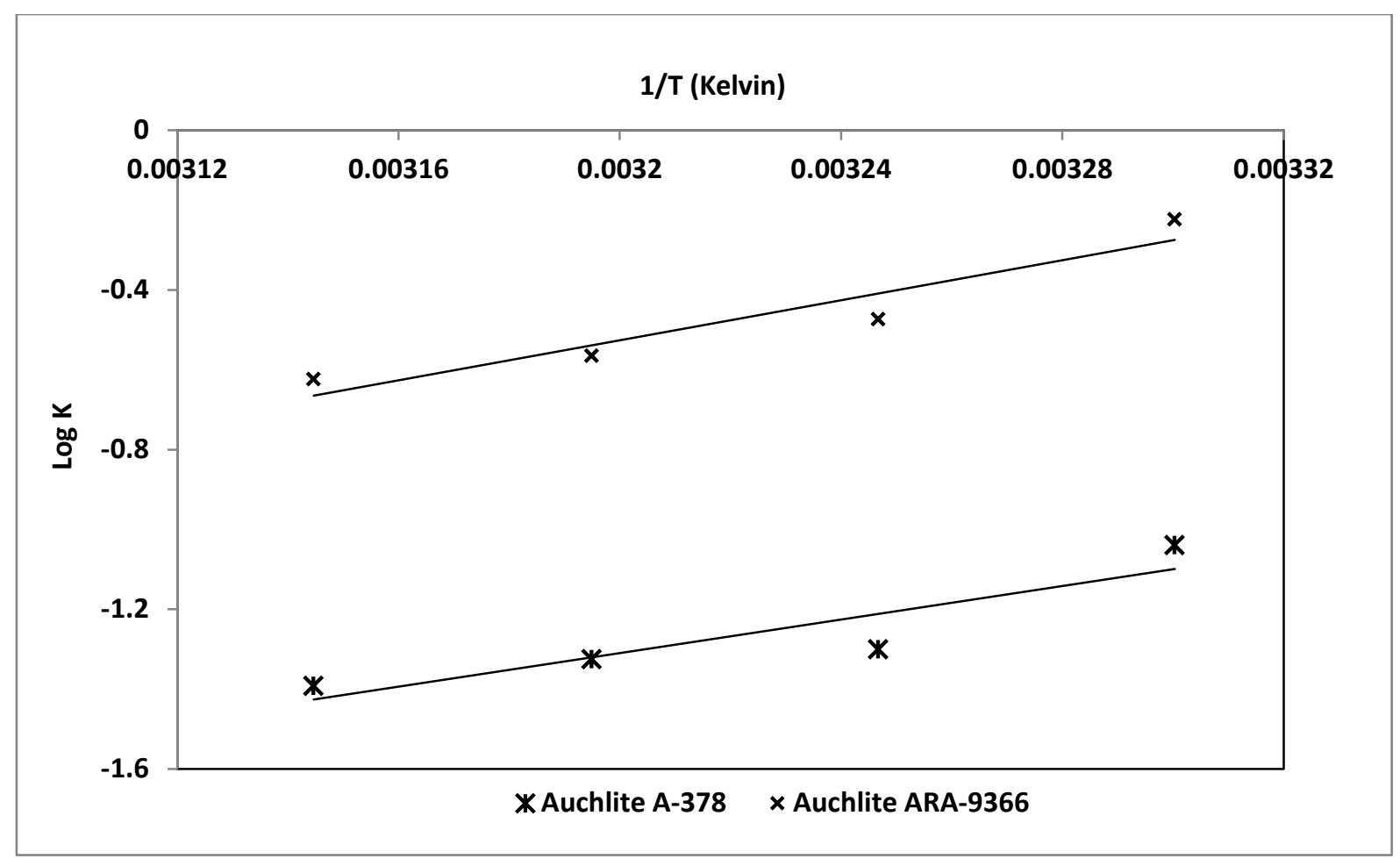

Figure 1. Effect of temperature on equilibrium constant of ion exchange reaction

$$
\mathrm{R}-\mathrm{Cl}+\mathrm{I}^{-} \leftrightarrow \mathrm{R}-\mathrm{I}+\mathrm{Cl}^{-}
$$

performed by using Auchlite ARA-9366 and Auchlite A-378 resins.

\section{CONCLUSION}

From the results of present study, it appears that the experimental technique used here can be applied further to understand the ionic selectivity of different industrial grade ion exchange resins. It is expected that such studies will provide valuable information in order to decide about the selection of those resins for efficient separation of various ionic species present in the industrial waste water effluents. 


\section{References}

[1] Marhol M., Comprehensive Analytical Chemistry, Ion Exchangers, XIV (1982) 117-160.

[2] Samanta S. K., Ramaswamy M., Misra B. M., Sep. Sci. Technol. 27 (1992) 255-267.

[3] Samanta S. K., Ramaswamy M., Sen P., Varadarajan N., Singh R. K., Removal of radiocesium from alkaline IL waste, Natl Symp. On Management of Radioactive and Toxic Wastes (SMART-93), Kalpakkam, 1993, Bhabha Atomic Research Centre, Bombay, 1993, 56-58.

[4] Samanta S. K., Theyyunni T. K., Misra B. M., J. Nucl. Sci. Technol. 32 (1995) 425-429.

[5] Kulkarni Y., Samanta S. K., Bakre S. Y., Raj K., Kumra M. S., Process for treatment of intermediate level radioactive waste based on radionuclide separation, Waste Management'96 (Proc. Int. Symp Tucson, AZ, 1996), Arizona Board of Regents, Phoenix, AZ (1996) (CD-ROM).

[6] Bray L. A., Elovich R. J., Carson K. J., Cesium Recovery using Savannah River Laboratory Resorcinol-formaldehyde Ion Exchange Resin, Rep. PNL-7273, Pacific Northwest Lab., Richland, WA (1990).

[7] Singare P. U., Lokhande R. S., Madyal R. S., Open Journal of Physical Chemistry 1(2) (2011) 45-54.

[8] Singare P. U., Lokhande R. S., Madyal R. S., Rus. J. Gen. Chem. 80(3) (2010) 527-532.

[9] Tomoi M., Yamaguchi, K., Ando R., Kantake Y., Aosaki Y., Kubota H., J. Appl. Poly. Sci. 64(6) (1997) 1161-1167.

[10] Zhu L., Liu Y., Chen J., Ind. Eng. Chem. Res. 48(7) (2009) 3261-3267.

[11] Kumaresan R., Sabharwal K. N., Srinivasan T. G., Vasudeva Rao P. R., Dhekane G., Solvent Extraction and Ion Exchange 24(4) (2006) 589-602.

[12] Cortina J. L., Warshawsky A., Kahana N., Kampel V., Sampaio C. H., Kautzman R. M., Reactive and Functional Polymers 54(1-3) (2003) 25-35.

[13] P. U. Singare, Int. J. Nucl. Energy Sci. and Technol. 8(2) (2014) 157-170.

[14] P. U. Singare, J. Nucl. Ene. Sci. Power Generat. Technol. 2(2) (2013) 1-6.

[15] Application of Ion Exchange Processes For the Treatment of Radioactive Waste and Management of Spent Ion Exchangers, Technical Reports Series No. 408, International Atomic Energy Agency, Vienna, (2002).

[16] Ion Exchange Technology I-Theory and Materials, Inamuddin, M.Luqman (Eds.), ISBN 978-94-007-1700-8 (eBook), DOI 10.1007/978-94-007-1700-8, Springer Dordrecht Heidelberg New York, London, (2012).

[17] G. H. Jeffery, J. Basset J. Mendham R. C. Denney, Ion Exchange, in Vogel's Textbook of Quantitative Chemical Analysis, 5th Ed., ELBS, Longman Scientific and Technical, England, 1989, pp. 208.

[18] P. U. Singare, Diffusion Fundamentals Online Journal 19(4) (2013) 1-21.

[19] P. U. Singare, International Letters of Chemistry, Physics and Astronomy 13 (2013) $37-49$. 
[20] P. U. Singare, International Letters of Chemistry, Physics and Astronomy 13 (2013) 50-62.

[21] P. U. Singare, International Letters of Chemistry, Physics and Astronomy 13 (2013) 63-76.

[22] P. U. Singare, International Letters of Chemistry, Physics and Astronomy 13 (2013) 77-89.

[23] P. U. Singare, International Letters of Chemistry, Physics and Astronomy 12 (2013) $1-13$.

[24] P. U. Singare, International Letters of Chemistry, Physics and Astronomy 12 (2013) 14-27.

[25] P. U. Singare, International Letters of Chemistry, Physics and Astronomy 6 (2013) $1-5$.

[26] P. U. Singare, Inter. J. Materials and Chemistry 2(4) (2012) 151-157.

[27] P. U. Singare, Phys. Chem. 2(4) (2012) 48-55.

[28] P. U. Singare, Science and Technology 2(5) (2012) 135-141.

[29] P. U. Singare, American J. Fluid Dynamics 2(5) (2012) 71-77.

[30] P .U. Singare, American J. Chem. 2(5) (2012) 263-270.

[31] P. U. Singare, Int. J. Composite Materials 2(6) (2012) 119-126.

[32] P. U. Singare, J. Nuclear and Particle Physics 2(5) (2012) 119-125.

[33] P. U. Singare, Frontiers in Science 2(6) (2012) 235-242.

[34] P. U. Singare, Advances in Anal. Chem. 2(5) (2012) 53-59.

[35] P. U. Singare, American J. Poly. Sci. 2(5) (2012) 115-121.

[36] P. U. Singare, Phys. Chem. 2(3) (2012) 37-42.

[37] Bonner O. D., Pruett R. R., J. Phys. Chem. 63 (1959) 1420.

[38] P. U. Singare, R. S. Lokhande, P. C. Vartak, Rasāyan J. Chem. 2(1) (2009) 96-100.

[39] P. U. Singare, R. S. Lokhande, P. C. Vartak, Rasāyan J. Chem. 2(4) (2009) 807-812.

[40] P. U. Singare, R. S. Lokhande, N. P. Vanmali, Rasāyan J. Chem. 2(2) (2009) 280-284.

[41] P. U. Singare, R. S. Lokhande, N. P. Vanmali, Rasāyan J. Chem. 2(4) (2009) 901-906. 